\title{
Digital Bangladesh - Vision 2021: What is the Digital Bangladesh Concept?
}

\author{
Dr. Anupam Mazumdar ${ }^{1}$, Husam Helmi Alharahsheh ${ }^{2 *}$ \\ ${ }^{1}$ Lecturer at University of Wales Trinity Saint David - London \\ ${ }^{2}$ Lecturer in Business Management at University of Wales Trinity Saint David - London and Senior Visiting Lecturer \\ Across Several UK and International Higher Education Institutions
}

\section{*Corresponding Author}

Husam Helmi Alharahsheh

\author{
Article History \\ Received: 28.01 .2020 \\ Accepted: 04.02.2020 \\ Published: 09.02.2020
}

\begin{abstract}
Bangladesh, one of the world's mostly densely populated countries, where former government of Bangladesh (Bangladesh Awami League (BAL), one of the political parties in Bangladesh, who formed the government in 2009 wanted to digitally develop the country by 2021. The plan of this development was one of the electoral manifestoes of the current Bangladesh government in 2008 before the ninth parliamentary election. This plan is widely known as "Digital Bangladesh - Vision 2021". This slogan attracted whole nations (mainly young citizens) and as a result they have been given an opportunity for the alliance of ruling parties to rule the country with a conclusive victory. The aim of this paper is to introduce the concept and terminologies of "Digital Bangladesh". This paper further aims to introduce main key elements/key outcomes of "Digital Bangladesh" concept.
\end{abstract}

Keywords: Bangladesh, Digital Bangladesh, Bangladesh Awami League (BAL), Vision 2021.

\section{Origin of the "Digital Bangladesh" concept}

"Change we can believe in" - the former US President Barak Obama's presidential election campaign slogan in 2008 inspired one of the political parties in Bangladesh, namely Bangladesh Awami League (BAL). They introduced concept of "Charter for Change" for their ninth parliamentary election manifesto in 2009, which worked well for them to win a convincing success in the election [1]. One major vision of the "Charter for Change" was to reach a "Digital Bangladesh" by 2021 [2].

Since the parliamentary election in 2009 in Bangladesh, the word "Digital Bangladesh" (DB) has become a very popular and day-to-day saying amongst the citizens [1]. "Digital Bangladesh": this buzzword has become governmental and organizational terminology, which has been used by the present governing party for expansion of any innovative decisions in relation to Information and Communication Technologies (ICTs). They (Bangladesh Awami League) believed that ICT can only play pivotal roles in the $21^{\text {st }}$ century in terms of economic development, personal awareness, connecting citizens to bring them under one umbrella, human resource development and etc [1]. The ruling government in Bangladesh has focussed on adopting advanced technology for the future and upon developing ICT sectors to adopt the globalization changes [3]. The term "Digital Bangladesh": Vision 2021", declared by the present ruling party in Bangladesh, Bangladesh Awami League (BAL), aimed to establish a resourceful, technology dependent modern country by the year 2021 (the country's 50 independence year) through effective use of Information and Communication Technology. Establishing "Digital Bangladesh" was a dream of present Bangladeshi Prime minster, Sheikh Hasina [3].

\section{Terminology of "Digital Bangladesh"}

The terminology of "Digital Bangladesh", does not merely carry the meaning of more comprehensive use of computers; it means that contemporary thinking of using and implementing advanced technologies such as Cloud Computing [4]. This terminology also means that how advanced technology (Cloud Computing) can be implemented in an effective way in poverty, education, health, business, job placement is a means by which business development, economic growth and social improvement may enhance opportunities and income for Bangladeshi citizens [3]. As Cloud Computing is the next step of ICT undoubtedly therefore, using Cloud Computing is the idea behind Digital Bangladesh

Copyright @ 2020: This is an open-access article distributed under the terms of the Creative Commons Attribution license which permits unrestricted use, distribution, and reproduction in any medium for non commercial use (NonCommercial, or CC-BY-NC) provided the original author and source are credited. 
terminology but Bangladesh government is not using the terminology "Cloud Computing" owing to the fact that majority of the citizens will not understand the concept. As a result, the ruling government of Bangladesh showed positive attitudes in their thinking and persuaded to implement innovative ideas for the success of their "Digital Bangladesh" policy [3]. The viewpoint of "Digital Bangladesh" includes rights and democracy for the peoples of Bangladesh such as transparency, accountability, establishing justice and guaranteeing distribution of government facilities to every door by use of technology and with the goal to facilitate routine tasks of citizens in Bangladesh [3]. The aim of "Digital Bangladesh" terminology is to build the proficiencies that are needed to compete in the globalized $21^{\text {st }}$ era by using less expensive delivery tools and digital learning environments [5].

\section{Definition of "Digital Bangladesh"}

"Digital Bangladesh" the dream of Bangladeshi Prime Minister Sheikh Hasina, is becoming a very important daily discussion topic among Bangladeshi IT specialists, journalists, politicians, students as well as policy makers [3]. However, what the "Digital Bangladesh" catchphrase precisely means is still unclear to many citizens in Bangladesh [6].

Although the government did not yet fully specify the definition of "Digital Bangladesh", however; government officials, business leaders, media personalities, academicians, non-government (NGO) heads and Information Technology (IT) specialists have developed their own individual meanings for "Digital Bangladesh" [3, 6, 7]. Some definitions of "Digital Bangladesh" provided are given below.

Table-1: Definitions of "Digital Bangladesh" [3, 8]

\begin{tabular}{|c|l|}
\hline Sector(s) & \multicolumn{1}{c|}{ Definition } \\
\hline Government & $\begin{array}{l}\text { "Digital Bangladesh" is a vision where the citizens of the country can get information through } \\
\text { electronic channels. Government services can be provided over electronic channels and the need for } \\
\text { human interaction will be minimal. It is to apply the latest advancements of science and technology } \\
\text { in the country. }\end{array}$ \\
\hline Business & $\begin{array}{l}\text { A Bangladesh that is globally competitive with the adoption of digital technology that enables a real } \\
\text { knowledge economy. }\end{array}$ \\
\hline "Digital Bangladesh", as people believe, is something that will solve most of the country's problems \\
such as corruption, unemployment, illiteracy, poverty and inflation. It is a gift of the newly elected \\
government that will come true by 2021.
\end{tabular}

From the characterisations above, this study attempts to arrive at a position to define "Digital Bangladesh". According to the authors of this study defined "Digital Bangladesh" is a policy for the creation of an ICT grounded modern nation, where use of the Internet, e-commerce, e-banking, e-governance, use of open-source software, wellnetworked software and acceptable power sources will be available constantly". From this characterisation of the concept of "Digital Bangladesh", it is now important to introduce various key elements of "Digital Bangladesh" into our study.

\section{Key Elements of "Digital Bangladesh"}

Under the concept of "Digital Bangladesh", ICT is one of the foremost enablers to the country's fight to attain the financial, communal and cultural freedom [9]. "Digital Bangladesh", in various ways is a re-creation of the dream "Sonar Bangla", which is called "Golden Bengal". One of the key motivations for "Digital Bangladesh" is the distinctive unfairness concerning the underprivileged comprising the majority of people [9]. Based on this view, it can be said that ICT and advanced technologies requirement to be leveraged in all the phases of national advancement of a "Digital Bangladesh" dream [9]. According to Access to Information (A2I) Programme, Prime Minister's Office [9], some of the key broad outcome areas in which ICT can be influenced is summarised below in the figure. The figure clearly shows that the "Digital Bangladesh" concept is entirely relying on four pillars namely Human Resource Development, Connecting Citizen, Digital Government and ICT in business. 


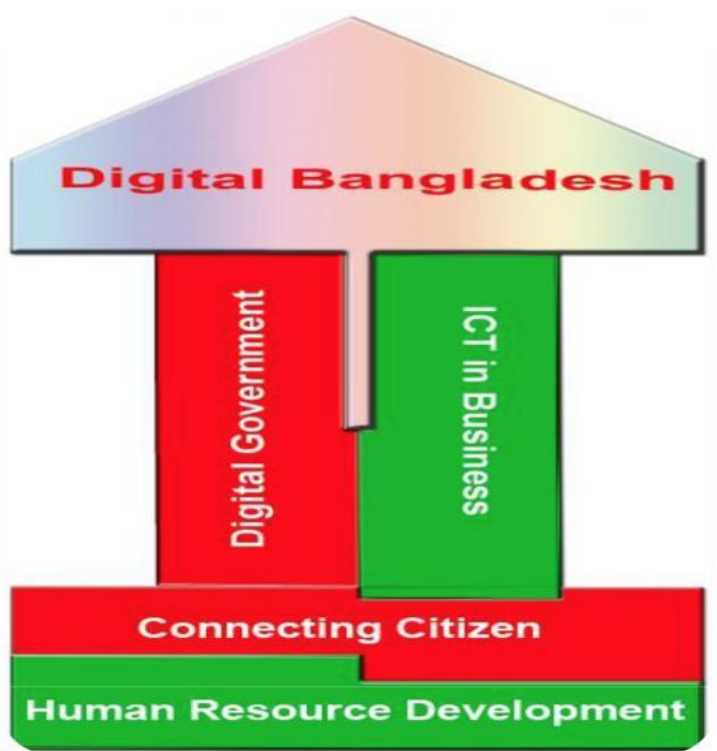

Figure: Key elements of "Digital Bangladesh" (Adapted from: Access to Information (A2I) Programme, Prime Minister's Office, 2009) [9]

\section{Human Resource Development (HRD)}

Human Resource Development is one of the vital components of "Digital Bangladesh" [9]. One point of the "Digital Bangladesh" concept is to bring more people into the ICT industry to raise skill levels who can move forward and enhance skill levels throughout the country [9]. According to Access to Information (A2I) Programme, Prime Minister's Office [9], "the key objective of "Digital Bangladesh" is to make the best use of new technologies to build world-class skills in all areas of study". The aim of "Digital Bangladesh" is to build the proficiencies that are needed to compete in the globalized $21^{\text {st }}$ era by using less expensive delivery tools and digital learning environments [9].

\section{Connecting Citizens}

Connecting citizens is another fundamental cornerstone of "Digital Bangladesh" concept, which entails guaranteeing access to "Digital Bangladesh" for every citizen. Finding right channels is the key objective of this component, so citizens can benefit from all that a "Digital Bangladesh" could offer [9]. The key aims of this component are (a) making people conscious and capable to access public-services leveraging ICTs, (b) concern related to native languages gratified and making local content available and (c) ground-breaking access to channels and platforms for common purposes [9].

\section{Digital Government for Pro-Poor Services}

In "Digital Bangladesh" policy, one of the key sub-components is provisioning ICT enabling services, such as eCitizen services, by public agencies. Priority should be given for those services that are critical for many citizens in various sectors [9]. The main deliverables of an e-Citizen service initiative are innovative service design and delivery channels that suit citizens' lifestyles, which means (1) reducing the number of interactions between service providers and recipients, (2) delivering in a speedy and cost effective way and (3) extending service availability to twenty four hours per day [9].

\section{ICT in Business}

The final pillar of "Digital Bangladesh" deals with three broad issues namely (i) access to markets, (ii) promotion of ICT business to support "Digital Bangladesh" (business productivity), and (iii) ICT as an export oriented sector or industry for local and export markets [10]. ICT-based market access mechanisms will not only benefit disadvantaged producers and businesses by ensuring equitable access to domestic and international markets but also will enable the government to establish transparent and efficient market monitoring by implementing ICT policies [10]. The key objective of this section is to influence ICTs to promote admittance to various marketplaces by less developed businesses. In addition, this component further includes leveraging ICTs to preserve communally accountable and an unbiased marketplace for all. Introducing ICT portals, which is called e-Tender is just an example of how ICTs could influence in different areas of the world to open new chances for the business [9].

The basic objective of this final pillar of "Digital Bangladesh" is to support the business industry especially SMEs to ensure that it may provide services and technology needed to sustain the other three components of "Digital Bangladesh" [9]. In addition, the third sub-section also includes the right foundation for the local businesses to access the international marketplace [11]. 


\section{CONCLUSION}

Undoubtedly, concept of "Digital Bangladesh" means using not only ICT but also advanced technology such as Cloud Computing in every sector throughout the country by citizens. In this study, we have tried to provide an overall idea of how ICT may bring changes in major outcome areas/key elements of the concept of "Digital Bangladesh. Although, government is trying to implement various strategies to transform the country digital but current perspective of Digital Bangladesh concept is still a dream. The country can be digitally developed by 2021 if the government honestly and clearly implements various ICT programs with a proper roadmap under a strong leadership.

\section{REFERENCES}

1. Islam, M., \& Grönlund, A. (2011). Digital Bangladesh - A Change We Can Believe in? [Retrieved from: <https://www.researchgate.net/publication/225100289_Digital_Bangladesh_-_A_Change_We_Can_Believe_in> Accessed on 24/06/2016]

2. Bangladesh Awami League Election Manifesto. (2008) [Retrieved from: <http://www.albd.org/autoalbd/index.php?option=com_content\&task=view\&id=367\&Itemid=1> Accessed on 24/06/2016]

3. Islam, S. (2018) Digital Bangladesh a reality now [adapted from: <https://www.dhakatribune.com/bangladesh/2018/07/11/digital-bangladesh-a-reality-now> accessed on 01/01/2019]

4. Habib, A., \& Baizid, A. R. (2010). Achievements and Expectations of Digital Bangladesh: e-Governance Initiatives in Bangladesh.

5. Hasan, M. (2010). What need to be done for Digital Bangaldesh [Adapted from: $<$ http://voipbangladesh.com/bangladesh-internet/what-need-to-be-done-for-digital-bangladesh-287.html> Accessed on: $19 / 11 / 2019]$

6. Genilo, J., Akther, M., \& Islam, S. (2010). Narratives on Digital Bangladesh: Shared Meanings, Shared Concerns. 4th Communication Policy Research: South Conference, Negombo, Sri Lanka

7. Habib, A., \& Faysal, M. R. (2009). Paperless Office: First Step to Digital Bangladesh, Proceedings of the International Conference of E-Governance (ICEGOV). Bogota, Colombia.

8. Genilo, J., Akther, M., \& Islam, M. (2009, December). Narratives on digital Bangladesh: Shared meanings, shared concerns. In Narratives on Digital Bangladesh: Shared Meanings, Shared Concerns (December 7, 2009). 4th Communication Policy Research: south Conference, Negombo, Sri Lanka.

9. Access to Information Programme, Prime Minister's Office. (2009). Digital Bangladesh: Concept Note. [Retrieved from:

<http://www.a2i.pmo.gov.bd/sites/default/files/resource_docs/Digital\%20Bangladesh\%20Concept\%20Note_Final.p df $>$ Accessed on 10/07/2016]

10. Access to Information Programme, Prime Minister's Office. (2011). Bangladesh: Access to Information Programme $\begin{array}{llll}\text { (A2I) Evaluation Report } \quad \text { [Retrieved } & \text { from: }\end{array}$ <http://www.a2i.pmo.gov.bd/sites/default/files/resource_docs/a2i\%20Evaluation\%20Report.pdf> Accessed on 10/07/2016]

11. Lasker, R. (2010). Digital Bangladesh down. The Daily Star (May 10, 2010) [Adapted from: < http://www.thedailystar.net/newDesign/news-details.php?nid=137790> Accessed on: 19/11/20. 